\title{
A Novel Approach for Inferring the Proportion of Terrestrial Organic Matter Input to Marine Sediments on the Basis of TOC:TN and $\delta^{13} C_{\text {org }}$ Signatures
}

\author{
Antonio Fernando Menezes Freire ${ }^{1}$, Marcelo Costa Monteiro ${ }^{2}$ \\ ${ }^{1}$ Department of Geochemistry, Petrobras Research Center, Rio de Janeiro, Brazil \\ ${ }^{2}$ Department of Sedimentology and Stratigraphy, Petrobras Research Center, Rio de Janeiro, Brazil \\ Email: fernandofreire@petrobras.com.br, marcelom@petrobras.com.br
}

Received November 25, 2012; revised February 21, 2013; accepted March 9, 2013

Copyright (C) 2013 Antonio Fernando Menezes Freire, Marcelo Costa Monteiro. This is an open access article distributed under the Creative Commons Attribution License, which permits unrestricted use, distribution, and reproduction in any medium, provided the original work is properly cited.

\begin{abstract}
The ratio of total organic carbon to total nitrogen (TOC:TN) and the stable carbon isotope ratio of organic matter $\left(\delta^{13} \mathrm{C}_{\text {org }}\right)$ are widely applied for inferring the origin of organic matter $(\mathrm{OM})$ in Quaternary marine sediments. A plot of TOC:TN vs. $\delta^{13} \mathrm{C}_{\text {org }}$ is useful for such studies but is strongly based on qualitative constraints. This study is based on the qualitative characterization of the source of Quaternary OM via analysis of TOC:TN and $\delta^{13} \mathrm{C}_{\text {org }}$ signatures, but also proposes a probability parameter, which combines both signatures, to infer the amount of Terrestrial OM Input (TOMI). This index provides a method for quantifying the proportion of terrestrial OM vs. marine OM in a more comprehensive manner. The TOMI index concept was applied to a study area in the Joetsu Basin, eastern margin of the Japan Sea, where previous studies have characterized the OM from the Last Glacial Maximum (LGM) to the present. The upwards increase in TOC indicates that OM production during the Holocene was higher than during the LGM. The enriched $\delta^{13} \mathrm{C}_{\mathrm{org}}$ signature upwards and decrease in TOC:TN suggest predominantly marine phytoplankton OM during the Holocene. Throughout the LGM, low OM production with depleted $\delta^{13} \mathrm{C}_{\text {org }}$ values and high TOC:TN values in the sediments suggest a predominantly $\mathrm{C}_{3}$ terrestrial plant source for the $\mathrm{OM}$. Using these data, it was possible to calculate a proxy for a sea level variation curve during that period and to investigate the influence of the proximity of the coastal line to the continental slope on the input of terrestrial material to the basin. The proposal provides information for the application of sequence stratigraphic concepts. The TOMI index could confirm that the proximity to the shoreline and shelf break has a strong influence on the input of terrestrial material during lowstand periods.
\end{abstract}

Keywords: $\delta^{13} \mathrm{C}_{\mathrm{org}}$; Joetsu Basin; Japan Sea; Terrestrial Organic Matter Input; TOMI Index; TOC:TN

\section{Introduction}

The identification of the sources of organic matter (OM) in marine sediments is important for inferring the contribution of terrestrial material since both terrestrial vegetation and soils can be delivered to the deeper parts of a basin along the geological time. During glacial stages, for example, the sea level was lowered by tens of meters and the input of terrestrial material became high at distal sites. During lowstands the mouths of the rivers were much closer to the continental shelf break, increasing the input of terrestrial material. Therefore, sea level curves can be generated using the terrestrial $\mathrm{OM}$ input as a proxy.

During such a sea level decline the occurrence of turbidite flows is common. The resulting sandy deposits associated with turbidities, if present, can be used to infer lowstands. A common interpretation is that the coarser the grain size, the closer the slope or coastal zone. On the other hand, in regions where there are no sandy sediments they represent distal parts of turbidite flows, so clayey sediments are dominant. In these cases, it is difficult to infer the provenance or location of the sediment source.

Therefore, the identification of terrestrial OM can be helpful for inferring both the input of continental clayey sediments and paleoenvironmental settings. Traditionally, the use of microfossil assemblages is an important tool, sometimes the only one, for reconstructing past sea level changes and paleoenvironmental conditions in marine regions. However the absence of microfossils from sedi- 
ments seriously hampers interpretation. This is critical for marine regions located below the carbonate compensation depth (CCD), where the carbonate body of marine organisms is totally or partially dissolved in the water column. As an alternative, the stable carbon isotope values $\left(\delta^{13} \mathrm{C}_{\text {org }}\right)$ combined with the ratio of total organic carbon (TOC) to total nitrogen (TN) has been used to infer the nature of the $\mathrm{OM}$ in Quaternary marine sediments.

A criterion for differentiating the origin of $\mathrm{OM}$ on the basis of $\delta^{13} \mathrm{C}_{\text {org }}$ values was previously proposed [1-4]. In general, the OM present in marine sediments is classified into three groups. The first is dominated by marine organisms with $\delta^{13} \mathrm{C}_{\text {org }}$ values between $-20 \%$ and $-22 \%$; the second has $\delta^{13} \mathrm{C}_{\text {org }}$ values from $-22 \%$ to $-25 \%$, and may contain a mixture of terrestrial and marine OM; the third shows $\delta^{13} \mathrm{C}_{\text {org }}$ values lower than $-25 \%$, implying a predominant supply of terrestrial OM.

This criterion is based on the fact that both photosynthetic processes and source of carbon are different between marine organisms and terrestrial plants. The primary carbon source for marine phytoplankton is seawater bicarbonate with a $\delta^{13} \mathrm{C}$ of ca. $0 \%$. In contrast, land plants use atmospheric $\mathrm{CO}_{2}$ as carbon source, with $\delta^{13} \mathrm{C}$ of ca. $-7 \%$ [4-6]. The difference in $\delta^{13} \mathrm{C}_{\text {org }}$ of ca. $7 \%$ between marine primary producers and land plants has been successfully used to elucidate the origin of recent OM in sediments [5,7].

Burdige [2] and Brodie et al. [8] report that $\delta^{13} \mathrm{C}_{\text {org val- }}$ ues can range from $-22 \%$ to $-35 \%$ for $\mathrm{C}_{3}$ plant-derived $\mathrm{OM}$ and from $-6 \%$ to $-18 \%$ o for $\mathrm{C}_{4}$ plant-derived $\mathrm{OM}$. Consequently, based on $\delta^{13} \mathrm{C}_{\text {org }}$ measurements alone, mixtures of organic carbon from $\mathrm{C}_{3}$ and $\mathrm{C}_{4}$ terrestrial plant sources can potentially resemble marine-derived OM [2, 9-11]. On the other hand, recent studies have revealed $\delta^{13} \mathrm{C}$-depleted marine phytoplankton with $\delta^{13} \mathrm{C}_{\text {org }}$ of ca. $-28 \%$ [12], which can lead to errors in the interpretation of the source of OM. Characterization of sedimentary $\mathrm{OM}$ only via $\delta^{13} \mathrm{C}_{\text {org }}$ values may lead to misleading results, demonstrating the need for combining it with other indicators such as the TOC:TN.

According to Prahl et al. [13] and Lamb et al. [6], high TOC:TN values $>20$ are characteristic of terrestrial vegetation as a result from the dominance of carbon-rich (and nitrogen-poor) biochemical classes (i.e., lignin and cellulose). On the other hand, TOC:TN for marine DOM and POM likely reflect their different sources, fluxes and residence times [14]. Marine OM has lower values between 4 and 20, depending on the type of OM: particulate or dissolved, bacterial mass, etc. $[1,3,4]$, in which nitrogen is fixed by protein-enriched organisms. Therefore, coupling $\delta^{13} \mathrm{C}_{\text {org }}$ with TOC:TN has been used to qualitatively assess the sources of OM in marine sediments [3,4,6,15-17].

The relationship between TOC content ( $\mathrm{wt} \%)$ and the
TN content $(\mathrm{wt} \%)$ gives an idea about both marine $\mathrm{OM}$ productivity as well about terrestrial $\mathrm{OM}$ input, whereas both $\delta^{13} \mathrm{C}_{\text {org }}(\%)$ and TOC:TN provide inferences about the origin of OM [4]. The parameters have different unit measurements $(\%$ and $\%$ or non-dimensional in the case of the ratio) and are commonly plotted vs. depth, or combined with each other into a qualitative cross plot. In previous studies, Freire et al. [16] and Freire [17] applied the qualitative relationship between TOC:TN and $\delta^{13} \mathrm{C}_{\mathrm{org}}$, combined with palynomorph studies, to deep marine sediment samples collected from piston cores in the eastern margin of the Japan Sea. These studies suggested different sources for OM between the Holocene and the late Pleistocene at three distinct sites located from nearby the base of the slope to open sea conditions.

The main objective of this work was to calculate a Terrestrial OM Input (TOMI) probability index by combining the parameters TOC:TN and $\delta^{13} \mathrm{C}_{\mathrm{org}}$, plotting them vs. depth in one single graph, providing a way of constructing a proxy for sea level variation on the basis of semi-quantitative data. Based on the data of Freire et al. [16], a practical application of the use of TOMI index is proposed to assign the sources of OM and the changes associated with OM deposition. Specifically, the study aimed to locate sequence stratigraphic surfaces based on the sea level curve generated from the TOMI index in the study area, via correlation with data from other authors.

\section{Geologic Setting}

The Japan Sea is a typical back-arc basin formed behind the island-arc system of the Japanese islands and initiated by the rifting of the eastern margin of the Eurasian continent at around $25 \mathrm{Ma}$ [18]. The opening of the continental land mass was almost complete by $15 \mathrm{Ma}$ [19]. During the middle Pliocene, the tectonic style changed to compressive and a series of NE-SW anticline-syncline structures were formed [20]. Umitaka Spur, Joetsu Knoll and Oki Trough are three of these anticline/syncline systems, located along the eastern margin of the Japan Sea (Figure 1) [17,21].

According to Oba et al. [22], significant inflow of fresh water occurred from $27 \mathrm{ka}$ cal BP to $20 \mathrm{ka}$ cal BP, resulting in the development of stratification and strong anoxic bottom conditions during the LGM, when the sea level dropped around $120 \mathrm{~m}$ below the present level. The shore line moved toward the shelf break and river discharge migrated up to the shelf slope margin (Figure 1). Only after $8 \mathrm{ka}$ cal BP was the modern oceanographic regime established, promoting the transition from anoxic to oxic bottom water conditions [23]. The Quaternary hemipelagic sediments of the Japan Sea consist mostly of clay to silty clay and are characterized by $\mathrm{cm}$ to $\mathrm{dm}$ alternation of bioturbated and thinly laminated (TL) layers, which are considered to have been deposited under an- 

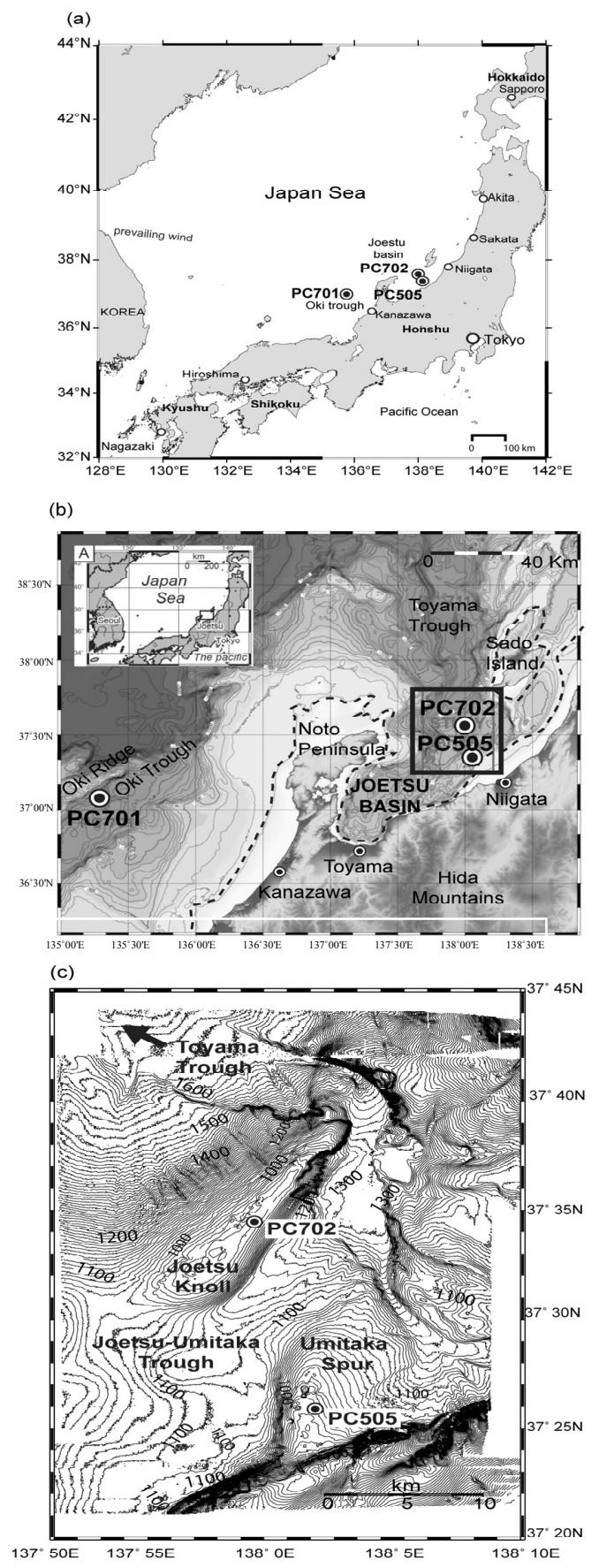

Figure 1. (a) Location map; (b) Location map of Joetsu Basin. Dashed line is a probable shore line during the LGM; (c) Cores location.

oxic to euxinic conditions [24].

\section{Materials and Methods}

\subsection{Sample Collection}

Several piston cores, 6 to $9 \mathrm{~m}$ long, were collected for gas hydrate research from the Joetsu Knoll, Umitaka Spur and surrounding areas since 2005 by the R/V Umi- taka Maru of the Tokyo University of Marine Science and Technology and by the R/V Kaiyo of the Japan Agency for Marine-Earth Science and Technology (JAMSTEC). These studies have been conducted by the University of Tokyo and other institutions, providing improvement in the geological knowledge of the eastern margin of the Japan Sea, particularly the Joetsu Basin [16, 17,21,25-27]. This study used three representative piston cores: PC701 (Oki Trough), PC702 (Joetsu Knoll) and PC505 (Umitaka Spur) to compare the OM at the three different locations, as related to the distance to the present shelf brake (Figure 1).

\subsection{Sub-Sampling and Analytical Methods}

From the three cores 223 samples were collected, each of ca. $5 \mathrm{ml}$. The sampling interval was ca. $10-15 \mathrm{~cm}$ in the upper part of the cores, until the presence of the first thinly laminated dark gray layer, and $5-10 \mathrm{~cm}$ between and within two thin laminated layers (TLs), to characterize the geochemical signatures for oxic and anoxic environments $[16,17]$. Lithologic units are described in Section 3.1 .

For TOC, TN and $\delta^{13} \mathrm{C}_{\text {org }}$ analysis, sediment samples were powdered and treated using $10 \% \mathrm{HCl}$ solution to remove carbonate. An aliquot of each sample was preserved for analysis of TC, with no acid treatment, to calculate TIC and to control the quality of the acid treatment by the comparison of both TOC and TIC values. The results are not discussed here, but are discussed in detail by Freire [17]. Acidified samples were dried on a hot plate at $55^{\circ} \mathrm{C}$ for 1 day and later in an oven at the same temperature for 4 additional days. The weight of each dried sample was measured before and after acid treatment for later normalization, considering possible salt formation and weight increase. Ca. $20 \mathrm{mg}$ of each sample were analyzed with a Thermo Finnigan Flash EA 1112 series CNS analyzer at the laboratory of the Department of Earth and Planetary Science of the University of Tokyo, using a retention time of $720 \mathrm{~s}$. The analytical error was $<0.2 \mathrm{wt} \%$ for $\mathrm{TOC}$ and $<0.02 \mathrm{wt} \%$ for $\mathrm{TN}$, using sulfametazine standard. The reproducibility error for duplicate analysis was $<0.5 \mathrm{wt} \%$ for TOC and $<0.05 \mathrm{wt} \%$ for TN.

\subsection{TOMI Index Calculation}

In order to calculate the Terrestrial Organic Matter Input (TOMI) probability index the following procedures were adopted:

1) Values suggesting a probability field for OM of terrestrial origin were empirically inferred from Lamb et al. [6], where a compilation of typical $\delta^{13} \mathrm{C}_{\text {org }}$ and TOC:TN values for organic inputs to coastal environments, described from several authors, was plotted. 
2) Twelve grid points (Table 1, column 3) were chosen from the probability field mentioned above, as key empirical probability values to be used for interpolation.

3) An interpolated surface grid of regularly spaced probability values was then generated by way of a kriging method, using software Surfer version 8.02, from the Golden Software, Inc. For the TOC:TN axis (x-axis), the grid line geometry was defined as a minimum of 0 and a maximum of 100 , with spacing of 0.1 and a total of 1001 cells. For the $\delta^{13} \mathrm{C}_{\text {org }}$ axis (y-axis) the grid line geometry adopted a minimum of $-34 \%$ and a maximum of $-10 \%$, with a spacing of $0.1 \%$ and a total of 241 cells.

4) Each pair of TOC:TN and $\delta^{13} \mathrm{C}_{\text {org }}$ values from analysis of a core sample was plotted onto the interpolated grid and the corresponding value of TOMI index was obtained and listed as an output file (Supplementary data 1).

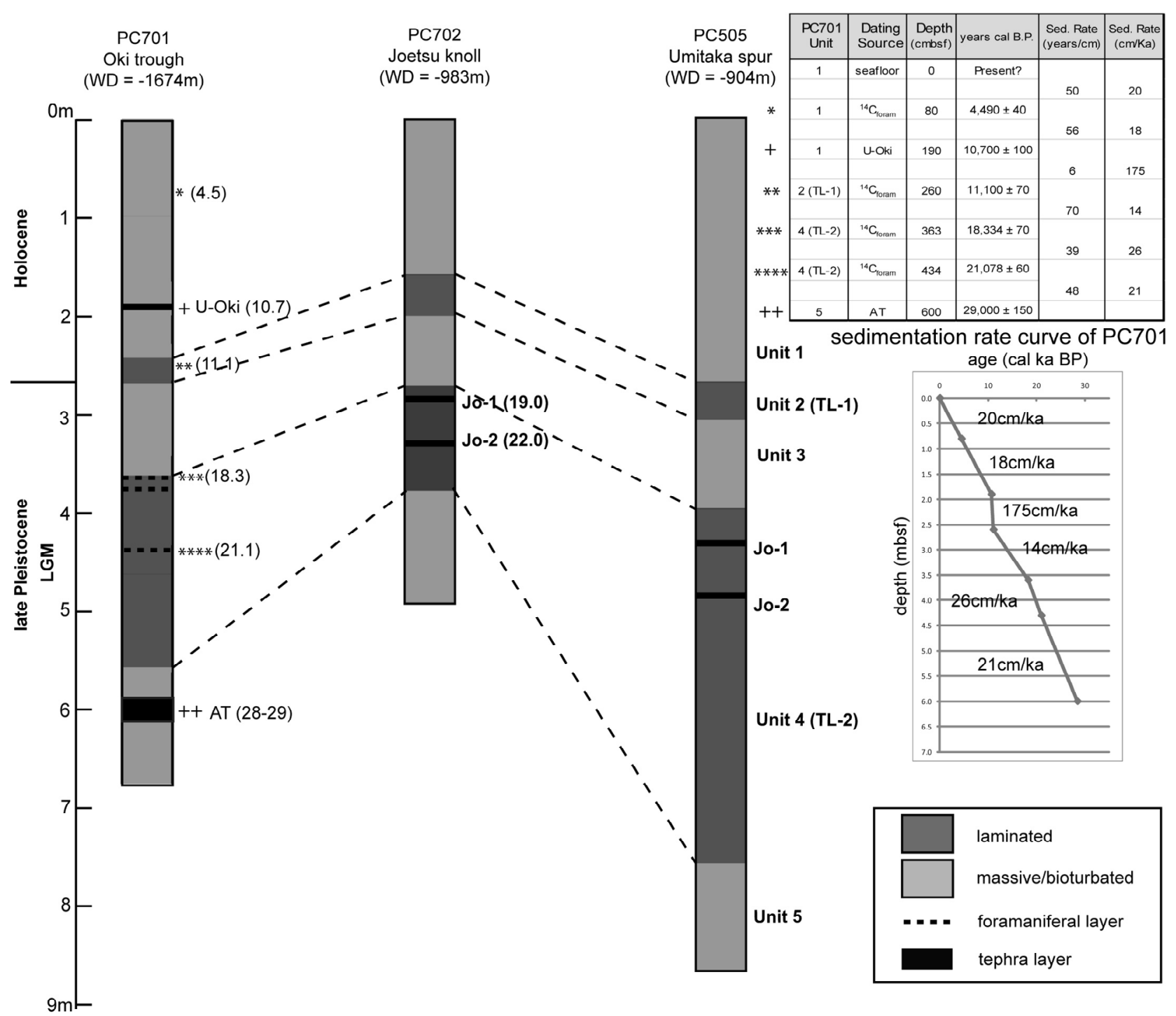

Table 1. Grid points chosen as key empirical probability values to be used for interpolation.

\begin{tabular}{ccc}
\hline TOC:TN & ${ }^{13} \mathrm{C}_{\text {org }}(\%$ PDB $)$ & TOMI index (\%) \\
\hline 4 & -10 & 0 \\
4 & -22 & 10 \\
4 & -25 & 20 \\
4 & -34 & 30 \\
10 & -10 & 20 \\
10 & -22 & 30 \\
10 & -25 & 40 \\
10 & -34 & 50 \\
100 & -10 & 90 \\
100 & -22 & 95 \\
100 & -25 & 98 \\
100 & -34 & 100 \\
\hline
\end{tabular}

Figure 2. Cores correlation between Oki Trough and Joetsu Basin. 


\section{Results}

\subsection{Core Descriptions and Age Control}

Five lithologic units were identified during core descriptions from the bottom to the top (Figure 2). Lithologic unit 5 is at the bottom, and is characterized by light gray bioturbated silty mud belonging to the early LGM sediments $[16,17]$. Unit 4 (TL-2) is characterized by thinly laminated dark gray mud deposited under anoxic conditions during the LGM lowstand. It corresponds to the TL-2 layer, one of the most important and widespread sedimentary records in the late Quaternary of the Japan Sea [24]. Unit 3 is a slightly bioturbated light gray silty mud, and represents the LGM/Holocene transition [16, 17]. Unit 2 (TL-1) is a $5-20 \mathrm{~cm}$ dark gray thinly laminated mud layer, which is also common in the Japan Sea. It was deposited under anoxic/sub-oxic bottom water conditions as a result of the water stratification caused by the inflow of fresh water during the beginning of the Holocene [24]. Finally, unit 1 is characterized by light gray bioturbated mud and represents the oxic bottom water conditions from the early-middle Holocene to the present $[16,17]$.

Two tephra were identified in PC701 (Oki Trough) and their glass shards and composition were correlated $[17,25]$ with the Atlas of Tephras in and around Japan [28]. The upper tephra is a pumice type in unit 1 , ca. 50 $\mathrm{cm}$ above the top of unit 2 (TL-1) at $1.88 \mathrm{~m}$ below the sea floor (mbsf-Figure 2), and was identified as Ulreung-Oki (U-Oki) tephra (10.7 ka cal BP) [28]. The lower tephra is a bubble wall glass type and is in the unit 5, ca. $50 \mathrm{~cm}$ below the base of unit 4 (TL-2) at $5.95 \mathrm{mbsf}$ (Figure 2). Both the shape and the composition are well correlated with the Aira-Tanzawa (AT) tephra (28 - $29 \mathrm{ka}$ cal BP) [28].

Two unknown tephra were recognized in the upper and middle part of unit 4 (TL-2) in the two cores from the Joetsu Basin (Figure 2) [17,25]. They were termed Joetsu-1 (Jo-1) and Joetsu-2 (Jo-2), and were cataloged by Freire [17] and Freire et al. [25]. Both tephra have now their glass shape and composition available for tephrostratigraphy along the eastern margin of the Japan Sea. Jo-1 can be classified as sodic calc-alkaline rhyolitic ash with grain size varying from fine to medium sand. Jo-2 is a very fine sand to silt sodic calc-alkaline rhyolitic ash. Ages of $19 \mathrm{ka}$ cal BP and $22 \mathrm{ka}$ cal BP are inferred for Jo-1 and Jo-2, respectively, based on the sedimentation rates obtained from tephrostratigraphy, unit correlations and ${ }^{14} \mathrm{C}$ dating $[17,25]$.

A total of four foraminifera samples were collected from PC701 for ${ }^{14} \mathrm{C}$ dating [16]: one sample of Neogloboquadrina dutertrei (warm water planktonic) at 0.80 mbsf in unit 1, and three of Globigerina umbilicata (cold water planktonic) at $2.60 \mathrm{mbsf}$ in unit 2 (TL-1), and at
3.63 and 4.34 mbsf respectively, both in unit 4 (TL-2). Dating results are summarized in Figure 2.

A depth-age conversion was made on the basis of tephrochronology, ${ }^{14} \mathrm{C}$ of foraminifera and lithologic unit correlation [16]. Consequently, it was possible to obtain a good correlation between the reference core PC701 (Oki Trough) and those from the Joetsu Basin (Figure 2). The top of unit 2 (TL-1) is inferred to occur at around $11.0 \mathrm{ka}$ cal BP, while the top of unit 3 is inferred to occur at $12.5 \mathrm{ka}$ cal BP. The top of unit 4 (TL-2) is placed around $18.0 \mathrm{ka}$ cal BP and the bottom at $26.0 \mathrm{ka} \mathrm{cal} \mathrm{BP,}$ which represents the top of unit 5 . The top of unit 1 is the seafloor.

High sedimentation rate values were observed for PC701 (Figure 2), located at a favorable depositional site (Figure 1; Oki Trough). For the Holocene [units 1 and 2 (TL-1)] a sedimentation rate of $19 \mathrm{~cm} / \mathrm{ka}$ was inferred, on average. An unusual ultra-rapid sedimentation rate of $175 \mathrm{~cm} / \mathrm{ka}$ was observed in the early Holocene, inferred from the presence of a well know tephra termed U-Oki (10.7 ka cal BP), but this still needs to be determined more accurately, using other cores. On the other hand, for the LGM, a sedimentation rate of $14 \mathrm{~cm} / \mathrm{ka}$ during the LGM/Holocene transition (unit 3) and around $24 \mathrm{~cm} / \mathrm{ka}$ during the maximum lowstand [units 4 (TL-2) and 5] was inferred.

\subsection{TOC, TN and $\delta^{13} \mathrm{C}_{\text {org }}$ Signatures}

Graphs comparing age vs. TOC (wt $\%$ ), age vs. ${ }^{13} \mathrm{C}_{\text {org }}(\%$ VPDB), age vs. TN (wt $\%$ ) and age vs. TOC:TN were constructed to promote an age-based correlation between Joetsu Basin and Oki Trough (Figure 3) [16,17]. TOC content from 0.5 to $2.0 \mathrm{wt} \%$ and $\delta^{13} \mathrm{C}_{\text {org }}$ varying from $-22.5 \%$ to $-26.0 \%$ characterize unit 5 at both locations. $\mathrm{TN}$ content decreases from 0.20 to $0.03 \mathrm{wt} \%$, resulting in an increase in TOC:TN from 9 to 58. Unit 4 (TL-2) is characterized by TOC content ca. 0.5 to $1.5 \mathrm{wt} \%$ and $\delta^{13} \mathrm{C}_{\text {org }}$ varying from -23.0 to $-26.0 \%$. The TN content is quite constant and low ca. $0.03 \mathrm{wt} \%$ in average but, despite this, the TOC:TN strongly oscillates from 14 to 96 (Figure 3).

TOC content increases from 0.5 to $1.5 \mathrm{wt} \%$ and ${ }^{13} \mathrm{C}_{\mathrm{org}}$ varies from $-23.8 \%$ at the base to $-21.7 \%$ at the top of unit 3, representing the LGM/Holocene geochemical transition. TN content rapidly increases from $0.06 \mathrm{wt} \%$ at the base to $0.19 \mathrm{wt} \%$ at the top, resulting in a decrease in TOC:TN from 46 at the base of unit 3 to around 10 at the top. Unit 2 (TL-1) is characterized by TOC content from 1.0 to $2.5 \mathrm{wt} \%$, and $\delta^{13} \mathrm{C}_{\text {org }}$ varying from $-21.0 \%$ to $-24.0 \%$. TN content increases up to $0.3 \mathrm{wt} \%$, resulting in TOC:TN $<20$. The shallower unit 1 is characterized by TOC content with a maximum value of $2.5 \mathrm{wt} \%$ at the base to a minimum of around $1.0 \mathrm{wt} \%$ at around $6.5 \mathrm{ka}$ 


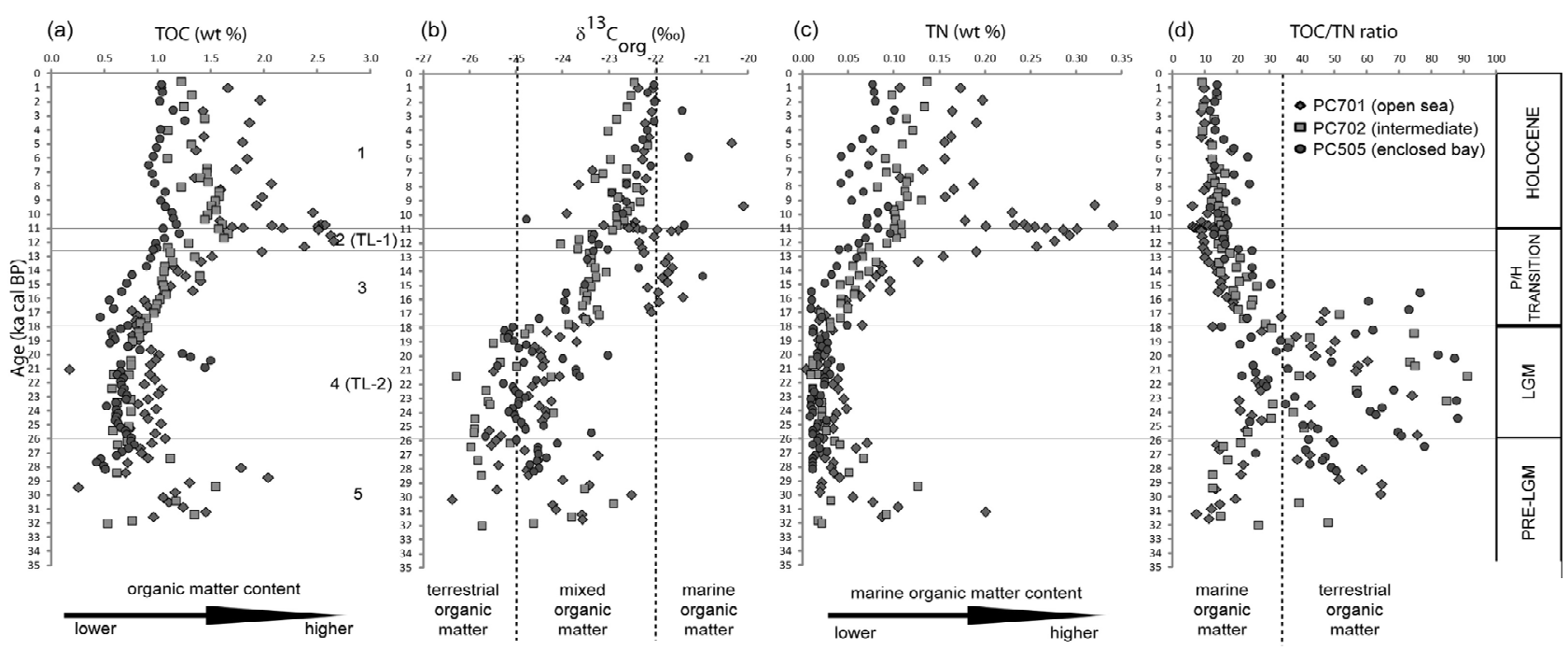

Figure 3. Geochemical crossplots. P/H: Pleistocene/Holocene boundary.

cal BP. The $\delta^{13} \mathrm{C}_{\text {org }}$ varies from $-22.4 \%$ at the base to $-20.1 \%$ in the upper part, representing the present Holocene sedimentation in the area. TN content decreeses from $0.25 \mathrm{wt} \%$ at the base to $0.11 \mathrm{wt} \%$ in the top, resulting in TOC:TN of nearly 10 on average.

\section{Discussion}

\subsection{Sources of OM on the Basis of TOC, TN and ${ }^{13} \mathrm{C}_{\text {org }}$}

The Holocene sediments of the Japan Sea are characterized by high TOC and TN contents, low TOC:TN values and enriched $\delta^{13} \mathrm{C}_{\text {org }}$ signatures (Figure 3), representing high marine productivity $[16,17]$. This is probably due to the input of phytoplankton from the Pacific Ocean to the Japan Sea as a result of the Holocene sea level rise [22]. The higher TOC and TN contents of unit 2 (TL-1), during the early Holocene, suggest a period of "blooming" and may result from the influx of marine organism-enriched water from the Pacific Ocean. This is corroborated by the presence of homogeneous amorphous OM, Pediastrum algae and foraminiferal tests [16]. On the other hand, the LGM sediments are characterized by low TOC and TN contents, high TOC:TN values and depleted $\delta^{13} \mathrm{C}_{\text {org }}$ signatures (Figure 3), characteristic of $\mathrm{C}_{3}$-derived terrestrial OM $[16,17]$, probably due to the large input of freshwater during the melting of snow, which carried large stocks of terrestrial sediments and OM [22]. This is also attested from the presence of cuticles and phytoclasts, characteristic of vascular plants [16].

Such paleoenvironmental interpretation is only possible if the analytical results represent a proxy for the chemical setting at the time of deposition. The use of $\delta^{13} \mathrm{C}_{\text {org }}$ and TOC:TN is a well establish stratigraphic tool and is widely applied to infer the origin of OM in Quaternary marine sediments. There is no doubt about the relationship between those parameters and paleoenvironmental interpretation [1-4,6,7,10-13,15]. However, recent studies indicate that bias resulting from sample acidification during pre-treatment with $\mathrm{HCl}$ [8] and early diagenetic processes [29-31] can alter both TOC:TN and the $\delta^{13} \mathrm{C}_{\text {org }}$ signatures of sedimentary $\mathrm{OM}$ with burial time/depth. Interpretation about the sources of OM based on TOC:TN and $\delta^{13} \mathrm{C}_{\text {org }}$ therefore needs to be carefully conducted. It is strongly recommended that these aspects are quantified and corrected before any speculation about the origin of OM. In the case of the data from the Japan Sea, used here to exemplify the use of the TOMI index, Freire et al. [16] and Freire [17] have shown some evidence that both influences (analytical bias and early diagenesis) are absent or negligibly low:

1) All the samples were analyzed for both TC (total carbon-with no $\mathrm{HCl}$ treatment) and $\mathrm{TOC}$ (with $\mathrm{HCl}$ treatment) for inferring total inorganic carbon (TIC), giving good quality control;

2) There are no macroscopic or microscopic indicators of early diagenesis, like carbonate concretions, cementation levels or framboidal pyrite;

3) Benthic and planktonic foraminipheral tests are well preserved along the section, with no dissolution and border erosion;

4) The presence of well preserved phytoclasts, cuticles and light orange amorphous OM, as well as the presence of non-ecloded copepods eggs, indicate rapid burial and preservation;

5) The high sedimentation rate values induced rapid burial and protection of OM from aerobic oxidation at the sea floor;

6) The absence of an increased and linear trend of results with depth/age, despite the lithology being almost the same (clay minerals) along the whole section;

7) Good correlation between the cores over long dis- 
tances $(>100 \mathrm{~km})$, preserving the same geochemical pattern for each lithologic unit. In a general, diagenesis is a local phenomenon and not correlated over long distances.

These observations suggest that the analytical data represent the depositional conditions and that diagenesis was not significant for disturbing the original record.

Spatially, analysis of the graphs (Figure 3) suggests that $\mathrm{OM}$ production during the Holocene highstand was higher in the open sea at Oki Trough (PC701) than in the enclosed and proximal settings of Umitaka Spur (PC505) and Joetsu Knoll (PC702) despite the OM content shows intermediate values in the latter. Moreover, this higher productivity is related to marine organisms because of the observed high TN content, low TOC:TN and enriched $\delta^{13} \mathrm{C}_{\mathrm{org}}$. On the other hand, the productivity during the LGM was lower than that of the Holocene, but was again higher for the open sea conditions of PC701 than the enclosed bay conditions of PC702 and PC505. Low TN content, depleted $\delta^{13} \mathrm{C}_{\text {org }}$ and high TOC:TN signatures suggest that the lower productivity during the LGM was strongly related to the input of terrestrial material caused by the seaward movement of the shore line, during this glacial period (Figure 1) [16,17].

The increased pattern in the TOC curve suggests that productivity rapidly increased from around $18 \mathrm{ka}$ cal BP to $12.5 \mathrm{ka}$ cal BP (Figure 3), probably due to the inflow from the Pacific Ocean during the early Holocene climate warming [32]. It strongly increased around $15 \mathrm{ka}$ cal BP and the same rapid shift is also apparent for both $\delta^{13} \mathrm{C}_{\text {org }}$ and TOC:TN curves, indicating the strong influence of marine organisms on the productivity during and after this period.

Figure 4(a) shows the relationship between TOC:TN and $\delta^{13} \mathrm{C}_{\text {org }}$ modified from the original compilation of Lamb et al. (2006): samples from unit 4 (TL-2) are widely distributed in the $\mathrm{C}_{3}$ terrestrial plant field $[6,8]$ with high TOC:TN and depleted $\delta^{13} \mathrm{C}_{\text {org }}$ [33]. Part of the unit 5 and unit 3 samples are also included in the $\mathrm{C}_{3}$ terrestrial plant-derived $\mathrm{OM}$ field, while other samples plot on the marine dissolved organic carbon (DOC) and particulate organic carbon (POC) fields, suggesting both units 5 and 3 are transition units between glacial and interglacial stages (Figure 4(a)). On the other hand, samples from units 2 (TL-1) and 1 almost plot in the marine POC, marine DOC, marine algae and bacteria fields (Figure 4(a)). The TOC:TN vs. $\delta^{13} \mathrm{C}_{\text {org }}$ cross plot is useful for inferring the presence of terrestrial OM, but does not accurately separate different marine OM components because the scale is very narrow in the marine organism ranges.

In an attempt to see the ranges of marine $\mathrm{OM}$ at higher resolution, a crossplot TN/TOC vs. ${ }^{13} \mathrm{C}_{\text {org }}$ cross plot is shown in Figure 4(b). The inverse of the TOC:TN was used to transform the established ranges compiled by Lamb et al. [6] (Figure 4(a)) to TN/TOC ranges (Figure

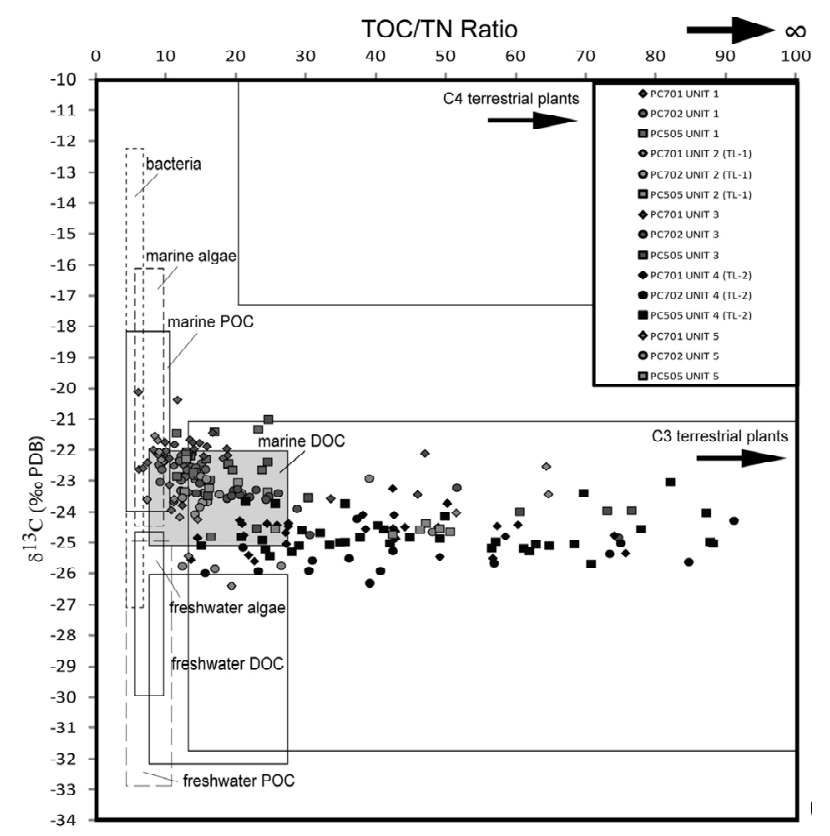

(a)

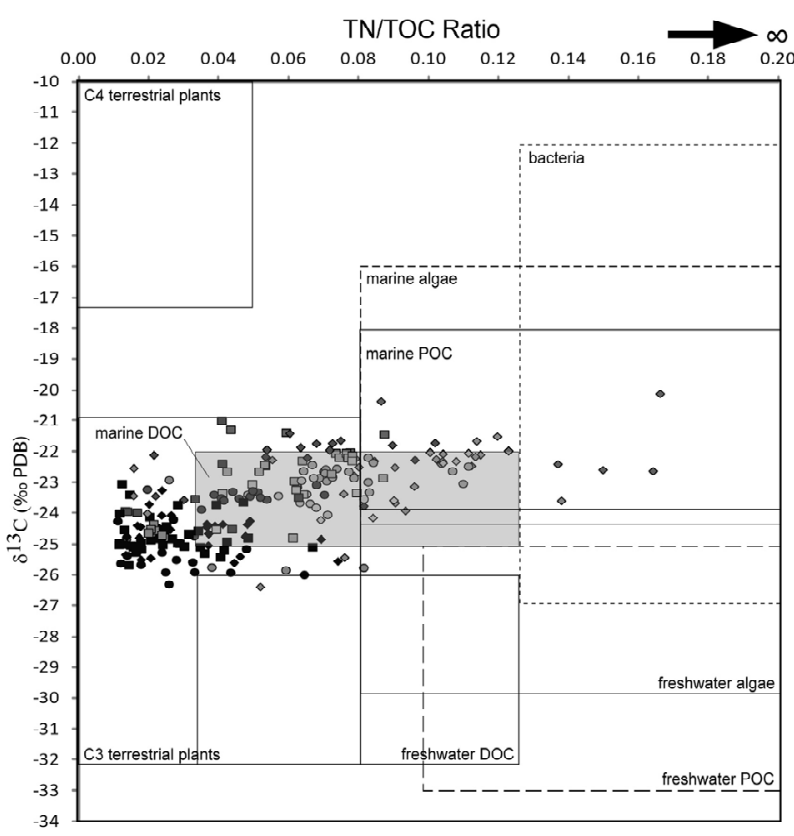

(b)

Figure 4. (a) Crossplot TOC/TN vs. $\delta^{13} \mathrm{C}_{\mathrm{CH} 4}$ (modified from Lamb et al., 2006); (b) Crossplot TN/TOC vs. $\delta^{13} \mathrm{C}_{\mathrm{CH} 4}$. Blue: unit 1; green: unit 2 (TL-1); red: unit 3; black: unit 4 (TL-2); orange: unit 5. Diamonds: PC701; circles: PC702; diamonds: PC505.

4(b)). Using this approach, it was easy to separate samples plotting in the marine OM range. However, both graphs show that is difficult to separate marine DOC from $\mathrm{C}_{3}$ terrestrial plants, because they overlap (Figure 4(a) and (b)). For this reason, the TOMI index for this region of the graph has $50 \%$ probability value, suggesting a mixture. The TN/TOC vs. $\delta^{13} \mathrm{C}_{\text {org }}$ graph would be a 
true property plot since carbon in on both axes, but it is unusual to see such a relationship in previous publications. For this reason this study is based on the usual and well establishes relationship of TOC:TN vs. $\delta^{13} \mathrm{C}_{\text {org }}$.

\subsection{The Terrestrial Organic Matter Input (TOMI) Probability Index}

As discussed in Section 4.1, TOC:TN and $\delta^{13} \mathrm{C}_{\text {org }}$ are frequently used to provide a qualitative distinction between terrestrial and marine OM. Lamb et al. [6] made an effort to compile the typical TOC:TN and $\delta^{13} \mathrm{C}_{\mathrm{org}}$ signatures for $\mathrm{OM}$ in coastal environments observed by several others. From that it is possible to infer qualitatively the boundaries for some organisms in terms of both TOC:TN and $\delta^{13} \mathrm{C}_{\text {org }}$ (Figure 4(a)). OM derived from marine POC, for example, ranges between 5 and 12 for TOC:TN and between $-18 \%$ and $-24 \%$ for $\delta^{13} \mathrm{C}_{\mathrm{org}}$ [6]. Qualitatively, it is helpful to infer the ranges for marine POC or other organic constituents, but it is difficult to quantify its proportion within a whole marine sediment sample. On the other hand, to provide an environmental discussion using core samples, it is necessary to create and compare two separate graphs: TOC:TN vs. depth or age and $\delta^{13} \mathrm{C}_{\text {org }}$ vs. depth or age. This is necessary because the values have different mathematical units and meanings, since the former suggests the OM source based on TN content (higher in marine organisms), whereas the latter, based on carbon isotope signature, reflects the source of carbon (atmosphere $\mathrm{CO}_{2}$ or dissolved bicarbonate).

In an attempt to combine both TOC:TN and $\delta^{13} \mathrm{C}_{\text {org }}$ data in a single curve, we propose the TOMI index. This is an approach to quantifying the amount of terrestrial $\mathrm{OM}$ in marine sediments through a probability calculation based on the ranges compiled by Lamb et al. [6]. End members were inferred from Figure 4(a): a TOMI index of $100 \%$ represents a pair with TOC:TN $\geq 100$ and $\delta^{13} \mathrm{C}_{\mathrm{org}} \leq-34 \%$, indicating that the sediment sample has $100 \%$ terrestrial OM (or 0\% marine OM). On the other hand, a TOMI index of $0 \%$ represents a pair with TOC:TN $=4$ and $\delta^{13} \mathrm{C}_{\mathrm{org}} \geq-20 \%$, indicating that the sediment sample has $0 \%$ terrestrial $\mathrm{C}_{3} \mathrm{OM}$ (or $100 \%$ marine $\mathrm{OM}$ ). Intermediate values between the end members were used for interpolation and the generation of probability values of TOMI index (Figure 5(a)). Analytical results can be plotted directly on the grid (Figure 5(b)). For future studies the TN/TOC vs. $\delta^{13} \mathrm{C}_{\mathrm{org}}$ relationship can be used to construct a more accurate index with respect to the marine OM constituents.

\subsection{Using the TOMI Index for Constructing Sea Level Curves as a Proxy (An Example)}

Relative changes in the sea level and rate of sediment supply are the main factors controlling transgression and regression events, which can be predicted within the

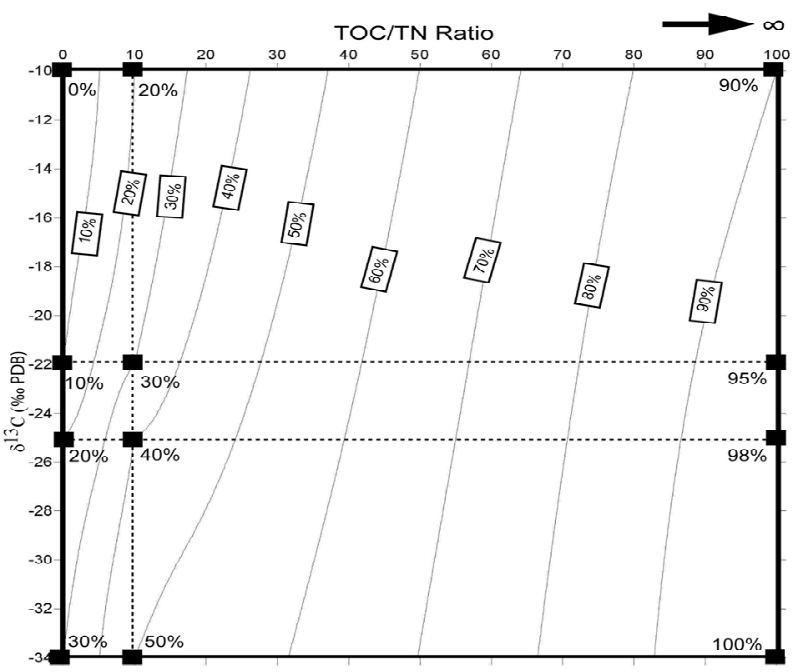

(a)

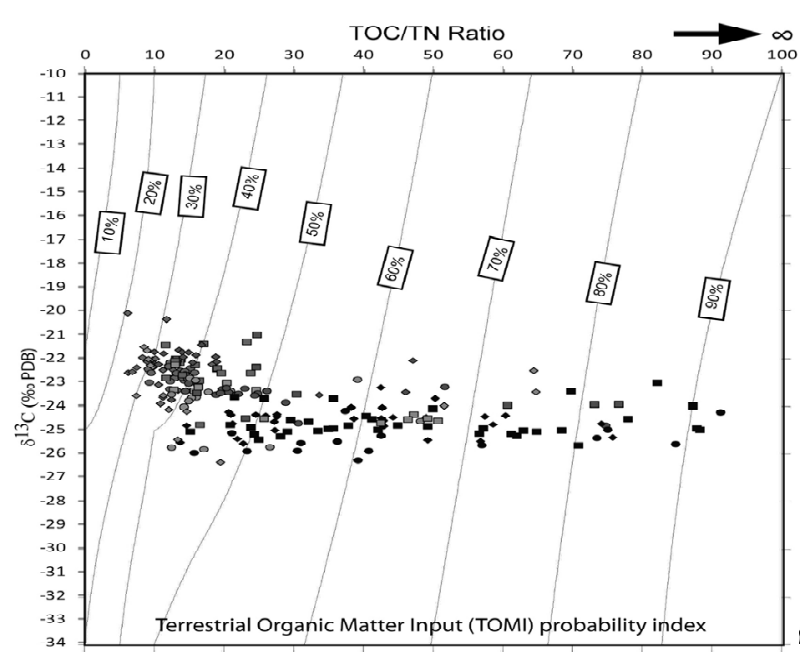

(b)

Figure 5. (a) Probability graph illustrating the amount of terrestrial OM in marine sediments; (b) Probability graph for calculation of the TOMI index. Colors and symbols are the same of Figure 4.

context of sequence stratigraphy. Regression is produced by relative sea level fall (forced regression) and/or excessive sediment supply (normal regression) [34]. In the case of the stratigraphic section studied here, a high resolution sequence stratigraphy analysis is necessary to understand the depositional history involving the late Pleistocene lowstand (LGM), caused by a strong forced regression that drops the sea level ca. $120 \mathrm{~m}$ below present and the subsequent Holocene highstand [22]. This sea level change could be detected by way of the TOMI index for clayey sediments, although changes in color are the only lithologic modification along the sedimentary section studied. Therefore, the TOMI index is a potential tool for inferring sea level change in clayey sections, where there is no visible evidence of lowstands, such as sandy turbidities. 
Two graphs were constructed here and can be used to infer sea level variation in the eastern margin of the Japan Sea during the last $30 \mathrm{ka}$, in particular at the Joetsu Basin and surrounding areas. The first plots the TOMI index vs. depth (Figure 6) and the second links the TOMI index to age (Figure 7). The latter was constructed on the basis of the age control and the sedimenttation rate values discussed in Section 3.1 and it was useful to combine all the cores in a single graph. Figure 6 shows independent graphs of TOMI index vs. depth for the three cores. Using the graphs it is possible to see that the shape of TOMI index curves are well correlated with each other, supported by the correlation between the lithologic units. Different thickness of the lithologic units can provide information about the variation in sedimenttation rate at different sites [17,25], but the TOMI index curve shows the same shape within the same unit in all the cores. This fact, associated to others discussed in Section 4.1, suggests a low diagenetic influence throughout the section.

To create an accurate depth-age conversion the most effective way is to have an age control for all the cores. Unfortunately, there is no age control for PC702 and PC505, so the age control is based only on the correlation with PC701 (Figure 2). Thus, the correlation between the three cores needs to be made carefully because there are small differences in the shape and position of the TOMI index curve, depending on the sedimentation rate for each core (Figure 6). The TOMI index strongly oscillates within unit 4 (TL-2) in all the cores, interpreted here as climate variation between relatively cooler and warmer periods within the LGM from around 27 to $17 \mathrm{ka}$ cal BP (Figure 7). An average TOMI index of 50\% is observed for PC701, while it is around 60\% for PC702

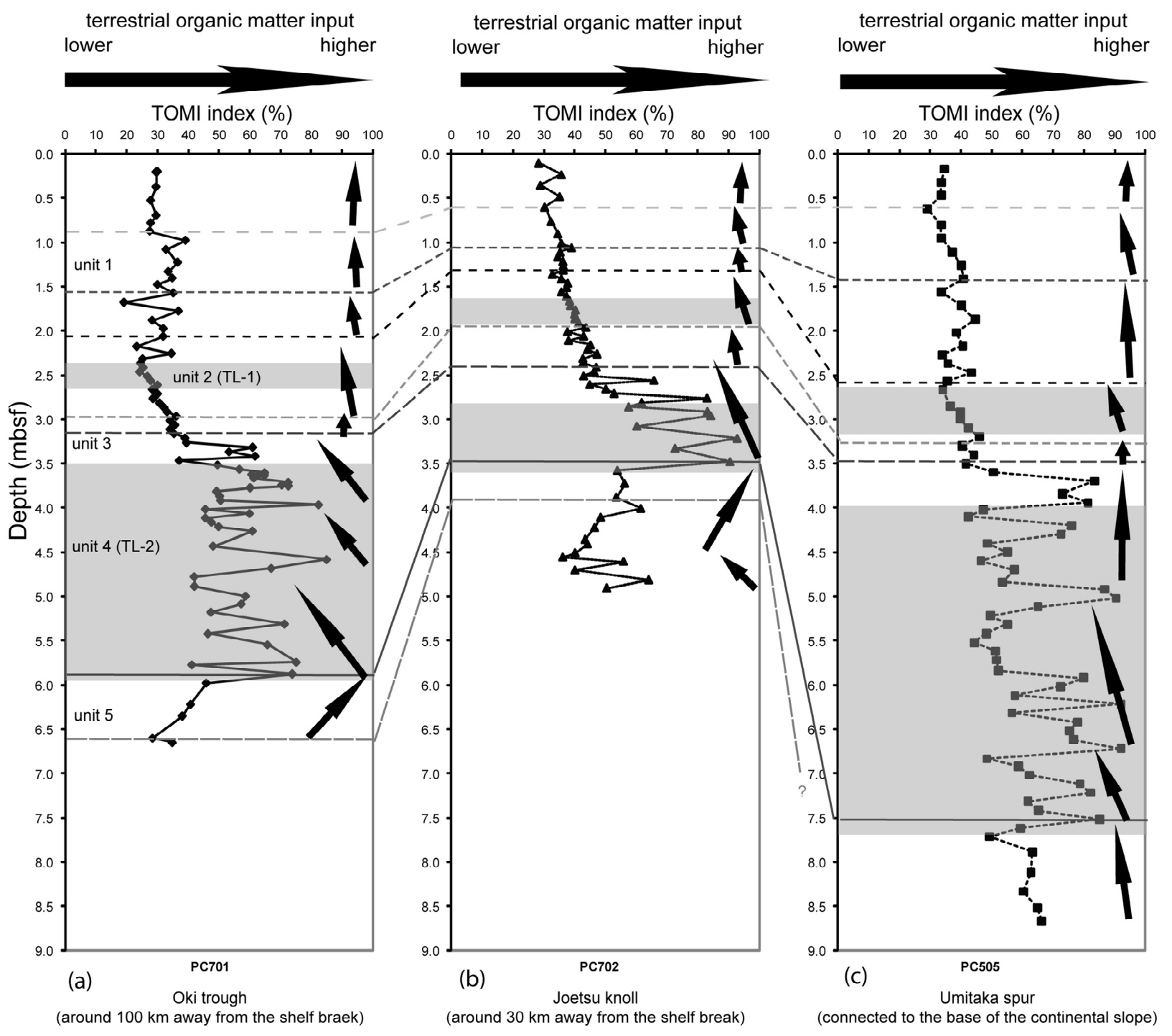

Figure 6. Graphic correlation using TOMI index curves. Arrows to the left: sea level rises; arrows to the right: sea levels falls; arrows to the top: aggradation. 


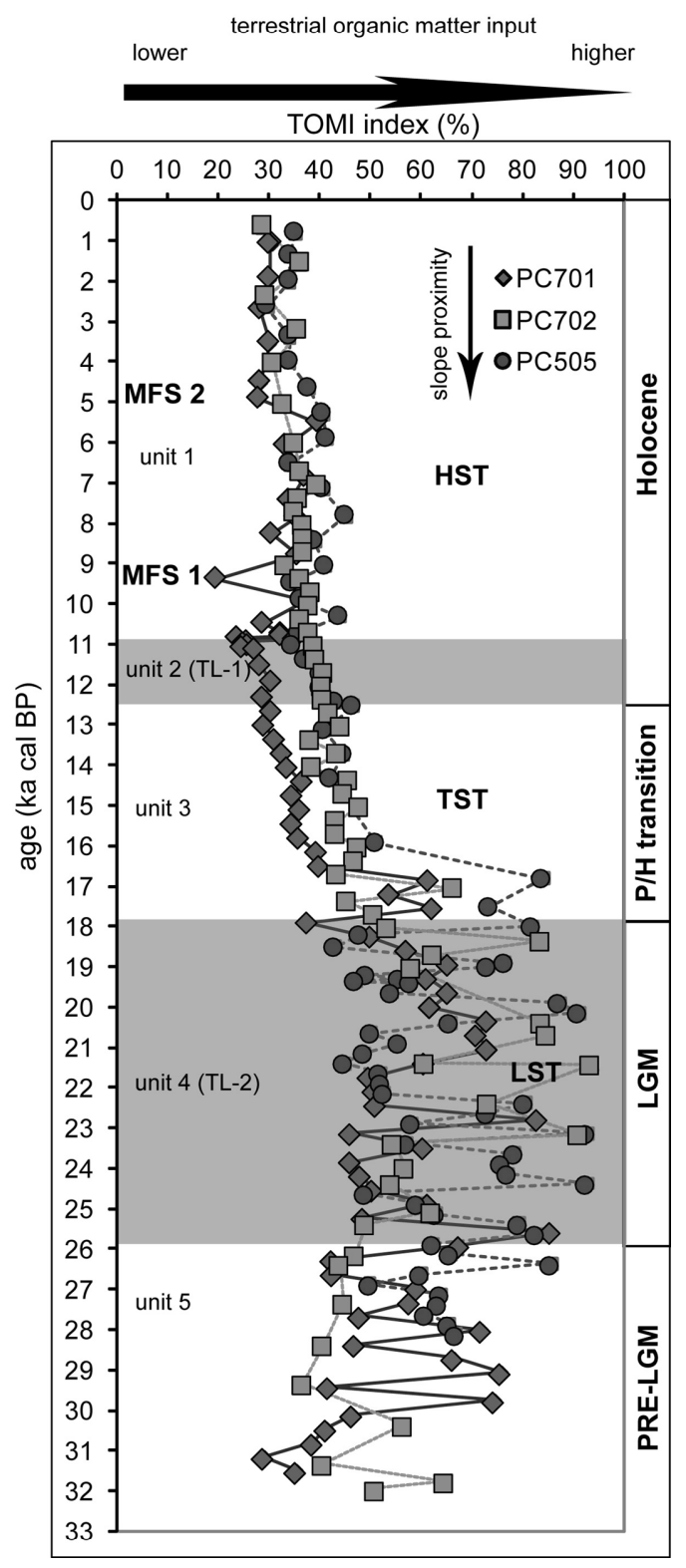

Figure 7. Crossplot age vs. TOMI index. HST: highstand system tract; TST: transgressive system tract; LST: lowstand system tract; MFS: maximum flood surface.

and $70 \%-80 \%$ for PC505, reflecting the proximity to the shelf break and the shoreline during the LGM lowstand (LST). The farther the distance from the terrestrial source the lower the TOMI index because it represents the amount of terrestrial OM. According to the index, the maximum lowstand occurred ca. 23 to $20 \mathrm{ka} \mathrm{cal} \mathrm{BP,}$ when the terrestrial input was higher (Figure 7). The maximum TOMI index is around $20 \mathrm{ka}$ cal BP in PC505, closer to the shelf break.

From 17 to $16 \mathrm{ka}$ cal BP a strong and rapid decrease occurs in the values of the index from $65 \%$ to $35 \%$ for PC701 indicating a shift to open sea conditions, reflecting a large input of plankton species from the Pacific
Ocean [22].

The same pattern was observed for both PC702 $(70 \%$ to $40 \%$ ) and PC505 (85\% to $50 \%$ ), suggesting that the inflow of Pacific Ocean water enriched in marine organisms was greater to Joetsu Basin. Using the TOMI index as indicative of sea level changes (Figure 7), the decrease of $25 \%-30 \%$ in terrestrial OM content in the short time of $1 \mathrm{ka}$ implies that paleoenvironmental conditions changed rapidly in the Japan Sea. Moreover, the rapid and strong sea level rise, previously accepted to occur at the beginning of the Holocene at $12.5 \mathrm{ka}$ cal BP [22-24], in fact occurred around $17-16 \mathrm{ka}$ cal BP, just after the end of the LGM. Climate variation alone does not support this strong decrease in the input of terrestrial OM because it is widely observed for the enclosed bay conditions of the Joetsu Basin and likewise the open sea setting of the Oki Trough, around $100 \mathrm{~km}$ away from the shelf break and shoreline. As discussed in Section 4.1, diagenetic processes were apparently insignificant in the section.

Between 16 and $11 \mathrm{ka}$ cal BP, the TOMI index decreases from $40 \%$ to $25 \%$ for PC701, $50 \%$ to $35 \%$ for PC702 and 55\% to $35 \%$ for PC505. As a proxy for the sea level variation, these trends suggest that sea level rose continuously during this period (Figure 7), inhibiting transfer of terrestrial material. The period represents a transgressive system tract (TST) linking the LGM lowstand to the Holocene highstand, which was recorded as a decreased pattern in the TOMI index, more intensely at the open sea than at enclosed bay conditions (Figure 7).

This is important to note the average difference in the TOMI index between PC701, PC702 and PC505 during the period, reflecting the strong influence of distance from the shoreline/shelf break on the input of terrestrial organic material.

At around 11 to $10.5 \mathrm{ka}$ cal BP a minimum in the index of ca. $20 \%$ is observed and, from then on until the present, it oscillates around $25 \%-35 \%$ on average at all sites (Figure 7). This probably represents the smaller contribution of terrestrial OM during the Holocene highstand (HST). Moreover, the small difference between the TOMI index for PC701, PC702 and PC505 during the Holocene indicates that the influence of the distance from the shoreline/shelf break is not so strong, as for the LGM lowstand, when the terrestrial input was higher.

Two minimum peaks occurs around $9 \mathrm{ka} \mathrm{cal} \mathrm{BP}$ and 5 ka cal BP, when the TOMI index is lower than the average at all sites. This may represent maximum flooding surfaces (MFSs) during the Holocene highstand. One coincides with the observation by Nakada et al. [35] who infer a maximum sea level rise of $5 \mathrm{~m}$ above present level at around $5 \mathrm{ka}$ cal BP. There is no known information regarding the sea level maximum associated with the peak at around $9 \mathrm{ka} \mathrm{cal} \mathrm{BP}$. 
The index reflects the terrestrial OM content present in marine sediments based on TOC, TN and $\delta^{13} \mathrm{C}_{\mathrm{org}}$. Thus, refining these parameters, with respect to the characteristics of both marine and terrestrial organisms, is critical for improvement in the use of the index curve as a proxy for sea level variation. Special attention should be given to a better characterization of marine DOC with respect to TOC:TN and $\delta^{13} \mathrm{C}_{\text {org }}$. The use of TOMI index is recommended at non-disturbed sediments. In the case of mounds and pockmarks, where the crystallization and dissociation of gas hydrates can alter the volume of sediments, causing an uplift of older sediments [36], the use of TOMI index can lead to errors of interpretation.

\section{Summary and Conclusions}

From this work, we conclude that:

1) The upwards increase in TOC indicates that OM production during the Holocene was higher than during the LGM in the study area. The enriched signature of $\delta^{13} \mathrm{C}_{\text {org }}$ upwards and the decrease in TOC:TN suggest predominantly phytoplankton-derived marine OM during the Holocene. Throughout the LGM, low OM production with depleted $\delta^{13} \mathrm{C}_{\text {org }}$ values and high TOC:TN suggests a predominantly $\mathrm{C}_{3}$ terrestrial plant source for the $\mathrm{OM}$ in the eastern margin of the Japan Sea.

2) The Terrestrial OM Input (TOMI) index is a promising tool for semi-quantifying the proportion of terrestrial $\mathrm{OM}$ in marine sediments. It can be used for validating the sea level curve based on other proxy measurements. Because the bulk parameters involved in this proxy are easy to determine, it can be applied for understanding paleoenvironmental conditions.

3) TOMI index could confirm that proximity to the shoreline and shelf break has a strong influence on the input of terrestrial material during lowstand periods, although it is not as important during highstand periods.

\section{Acknowledgements}

The authors are thankful to R. O. Kowsmann, D. J. Miller, J. V. P. Guzzo and M. Arai for comments. Thanks go to the anonymous reviewers for their comments and suggestions.

\section{REFERENCES}

[1] O. K. Bordovsky, "Sources of Organic Matter in Marine Basins," Marine Geology, Vol. 3, No. 1-2, 1965, pp. 5-31. doi:10.1016/0025-3227(65)90003-4

[2] D. Burdige, "Geochemistry of Marine Sediments," Princeton University Press, New Jersey, 2006.

[3] P. A. Meyers, "Preservation of Elemental and Isotopic Source Identification of Sedimentary Organic Matter," Chemical Geology, Vol. 114, No. 3-4, 1994, pp. 289-302. doi:10.1016/0009-2541(94)90059-0
[4] P. A. Meyers, "Organic Geochemical Proxies of Paleoceanographic, Paleolimnologic and Paleoclimatic Processes," Organic Geochemistry, Vol. 27, No. 5-6, 1997, pp. 213- 250. doi:10.1016/S0146-6380(97)00049-1

[5] K. H. Freeman, "Isotopic Biogeochemistry of Marine Organic Carbon," Reviews in Mineralogy and Geochemistry, Vol. 43, No. 1, 2001, pp. 579-605. doi:10.2138/gsrmg.43.1.579

[6] A. L. Lamb, G. P. Wilson and M. J. Leng, "A Review of Coastal Paleoclimate and Relative Sea-Level Reconstructions Using $\delta{ }^{13} \mathrm{C}$ and $\mathrm{C} / \mathrm{N}$ Ratios in Organic Material," Earth-Science Reviews, Vol. 75, No. 1-4, 2006, pp. 29-57. doi:10.1016/j.earscirev.2005.10.003

[7] J. Hoefs, "Stable Isotope Geochemistry," Springer-Verlag, Berlin, 2004. doi:10.1007/978-3-662-05406-2

[8] C. R. Brodie, M. J. Leng, J. S. L. Casford, C. P. Kendrick, J. M. Lloyd, Z. Yongqiang and M. I. Bird, "Evidence for Bias in $\mathrm{C}$ and $\mathrm{N}$ Concentrations and $\delta{ }^{13} \mathrm{C}$ Composition of Terrestrial and Aquatic Organic Materials Due to PreAnalysis Acid Preparation Methods," Chemical Geology, Vol. 282, No. 3-4, 2011, pp. 67-83. doi:10.1016/i.chemgeo.2011.01.007

[9] T. S. Bianchi, S. Mitra and B. McKee, "Sources of Terrestrially Derived Carbon in the Lower Mississippi River and Louisiana Shelf: Importance for Differential Sedimentation and Transport at the Coastal Margin," Marine Chemistry, Vol. 77, No. 2-3, 2002, pp. 211-223. doi:10.1016/S0304-4203(01)00088-3

[10] T. S. Bianchi, L. A. Wysocki, K. M. Schneider, T. R. Filley, D. R. Corbet and K. Kolker, "Sources of Terrestrial Organic Carbon in the Louisiana Shelf (USA): Evidence for the Importance of Coastal Marsh Inputs," Aquatic Geochemistry, Vol. 17, No. 4-5, 2011, pp. 431456. doi:10.1007/s10498-010-9110-3

[11] M. A. Gõni, K. C. Ruttemberg and T. I. Eglinton, “A Reassessment of the Sources and Importance of LandDerived Organic Matter in Surface Sediments from Gulf of Mexico," Geochimica et Cosmochimica Acta, Vol. 62, No. 18, 1998, pp. 3055-3075.

doi:10.1016/S0016-7037(98)00217-8

[12] M. A. Goñi and J. I. Hedges, "Sources and Reactivities of Marine-Derived Organic Matter in Coastal Sediments as Determined by Alkaline CuO Oxidation," Geochimica et Cosmochimica Acta, Vol. 59, No. 14, 1995, pp. 29652981. doi:10.1016/0016-7037(95)00188-3

[13] F. G. Prahl, J. T. Bennett and R. Carpenter, "The Early Diagenesis of Aliphatic Hydrocarbons and Organic Matter in Sedimentary Particulates from Dabob Bay, Washington," Geochimica et Cosmochimica Acta, Vol. 44, No. 12, 1980, pp. 1967-1976. doi:10.1016/0016-7037(80)90196-9

[14] A. N. Loh, J. E. Bauer, "Distribution, Partitioning and Fluxes of Dissolved and Particulate Organic C, N and P in the Eastern North Pacific and Southern Oceans," DeepSea Research I, Vol. 47, No. 12, 2000, pp. 2287-2316. doi:10.1016/S0967-0637(00)00027-3

[15] M. Denny, "How the Ocean Works: An Introduction to Oceanography," Princeton University Press, Princeton, 2008.

[16] A. F. M. Freire, T. R. Menezes, R. Matsumoto, T. Sugai 
and D. J. Miller, "Origin of Organic Matter in the LateQuaternary Sediments of the Eastern Margin of Japan Sea," Journal of the Sedimentological Society of Japan, Vol. 68, No. 2, 2009, pp. 117-128. doi: $10.4096 /$ jssj.68.117

[17] A. F. M. Freire, "An Integrated Study on the Gas Hydrate Area of Joetsu Basin, Eastern Margin of Japan Sea, Using Geophysical, Geological and Geochemical Data," Ph.D. Thesis, University of Tokyo, Tokyo, 2010, p. 247.

[18] K. Tamaki and N. Isezaki, "Tectonic Synthesis of the Japan Sea Based on the Collaboration of the Japan-URSS Monograph Project," In: N. Isezaki, et al., Eds., Geology and geophysics of the Japan Sea (Japan-Russia Monograph Series, Vol. 1)," Terra Scientific Publishing Company, Tokyo, 1996, pp. 483-487.

[19] L. Jolivet, K. Tamaki and M. Fournier, "Japan Sea, Opening History and Mechanism: A Synthesis," Journal of Geophysical Research, Vol. 99, No. B11, 1986, pp. 2223722259.

[20] A. Okui, M. Kaneko, S. Nakanishi, N. Monzawa and H. Yamamoto, "An Integrated Approach to Understanding the Petroleum System of a Frontier Deep-Water Area, Offshore Japan," Petroleum Geoscience, Vol. 14, No. 3, 2008, pp. 1-12. doi:10.1144/1354-079308-765

[21] A. F. M. Freire, R. Matsumoto and L. A. Santos, "Structural-Stratigraphic Control on the Umitaka Spur Gas Hydrates of Joetsu Basin in the Eastern Margin of Japan Sea," Marine and Petroleum Geology, Vol. 28, No. 10, 2011, pp. 1967-1978. doi:10.1016/j.marpetgeo.2010.10.004

[22] T. Oba, M. Kato, H. Kitazato, I. Koizumi, A. Omura, T. Sakai and T. Takayana, "Paleoenvironmental Changes in the Japan Sea during the Last 85,000 Years," Paleoceanography, Vol. 6, No. 4, 1991, pp. 499-518. doi:10.1029/91PA00560

[23] I. Koisumi, R.Tada, H. Narita, T. Irino, T. Aramaki, T. Oba and H. Yamamoto, "Paleoceanographic History around the Tsugaru Strait between the Japan Sea and the Northwest Pacific Ocean Since 30 Cal Kyr BP," Palaeogeography, Palaeoclimatology, Palaeocology, Vol. 232, No. 1, 2006, pp. 36-52. doi:10.1016/j.palaeo.2005.09.003

[24] R. Tada, T. Irino and I. Koizumi, "Land-Ocean Linkages over Orbital and Millennial Timescales Recorded in the Late Quaternary Sediments of the Japan Sea," Paleoceanography, Vol. 14, No. 2, 1999, pp. 236-247. doi:10.1029/1998PA900016

[25] A. F. M. Freire, T. Sugai, R. Matsumoto, "The Use of Tephras for Stratigraphic Correlation: A Case Study on the Eastern Margin of Japan Sea," Boletim de Geociências da Petrobras, Vol. 18, No. 1, 2010, pp. 97-121.

[26] A. Hiruta, G. T. Snyder, H. Tomaru and R. Matsumoto, "Geochemical Constraints for the Formation and Dissociation of Gas Hydrate in an Area of High Methane Flux,
Eastern Margin of the Japan Sea," Earth and Planetary Science Letters, Vol. 279, No. 3-4, 2009, pp. 326-339. doi:10.1016/j.epsl.2009.01.015

[27] R. Matsumoto, "Formation and Collapse of Gas Hydrate Deposits in High Methane Flux Area of the Joetsu Basin, Eastern Margin of Japan Sea," Journal of Geography, Vol. 118, No. 2, 2009, pp. 43-71.

[28] H. Machida and F. Arai, "Atlas of Tephra in and around Japan," University of Tokyo Press, Tokyo, 2003.

[29] M. Brenner, T. J. Whitmore, J. H. Curtis, D. A. Hodell and C. L. Schelske, "Stable Isotope $\left(\delta^{13} \mathrm{C}\right.$ and $\left.{ }^{15} \mathrm{~N}\right) \mathrm{Sig}$ natures of Sedimented Organic Matter as Indicators of Historic Lake Trophic State," Journal of Paleolimnology, Vol. 22, No. 2, 1999, pp. 205-221. doi:10.1023/A:1008078222806

[30] P. Chouldhary, J. Routh and G. J. Chakrapani, “Organic Geochemical Record of Increased Productivity in Lake Naukuchiyatal, Kumaun Himalayas, India," Environmental Earth Science, Vol. 60, No. 4, 2010, pp. 837-843. doi:10.1007/s12665-009-0221-3

[31] V. Gälman, J. Rydberg, S. S. de-Luna, R. Bindler and I. Renberg, "Carbon and Nitrogen Loss Rates during Aging of Lake Sediments: Changes over 27 Years Studied in Varved Lake Sediments," Limnology Oceanography, Vol. 53, No. 3, 2008, pp. 1076-1082. doi: $10.4319 / 10.2008 .53 .3 .1076$

[32] J. P. Kennett, K. G. Cannariato, I. L. Hendy and I. L. Behl, "Methane Hydrates in Quaternary Climate Changes: The Clathrate Gum Hypothesis," American Geophysical Union, Washington DC, 2003. doi:10.1029/054SP

[33] E. S. Gordon, M. A. Goñi, "Sources and Distribution of Terrigenous Organic Matter Delivered by the Atchafalaya River to Sediments in the Northern Gulf of Mexico," Geochimica et Cosmochimica Acta, Vol. 67, No. 13, 2003, pp. 2359-2375. doi:10.1016/S0016-7037(02)01412-6

[34] H. W. Posamantier, G. P. Allen, D. P. James and M. Tesson, "Forced Regressions in a Sequence Stratigraphic Framework: Concepts, Examples, and Exploration Significance," American Association of Petroleum Geologists Bulletin, Vol. 87, 1992, pp. 1687-1709.

[35] M. Nakada, N. Yonekura and K. Lambeck, "Late Pleistocene and Holocene Sea-Level Changes in Japan: Implications for Tectonic Histories and Mantle Rheology," Palaeogeography, Palaeoclimatology, Palaeoecology, Vol. 85, No. 1-2, 1991, pp. 107-122. doi:10.1016/0031-0182(91)90028-P

[36] A. F. M. Freire and M. C. Monteiro, "Geochemical Analysis as a Complementary Tool to Estimate the Uplift of Sediments Caused by Shallow Gas Hydrates in Mounds at the Seafloor of Joetsu Basin, Eastern Margin of the Japan Sea," Journal of Geological Research, Vol. 2012, Article ID: 839840, 2012, pp. 1-14. doi: $10.1155 / 2012 / 839840$ 


\section{Supplementary Data 1}

TOMI index for samples collected in the Japan Sea.

\begin{tabular}{|c|c|c|c|c|}
\hline SAMPLE NUMBER & Depth (mbsf) & $\mathrm{d}^{13} \mathrm{C}$ PDB \%o & TOC/TN Ratio & TOMI index (\%) \\
\hline $701-1-1$ & 0.20 & -22.39 & 9.68 & 30.13 \\
\hline $701-1-1 d$ & 0.21 & -22.06 & 9.62 & 29.68 \\
\hline $701-2-1 d$ & 0.38 & -22.02 & 9.98 & 29.68 \\
\hline $701-2-1$ & 0.53 & -22.09 & 8.72 & 27.90 \\
\hline $701-2-2 d$ & 0.70 & -22.23 & 9.80 & 29.68 \\
\hline $701-2-2$ & 0.78 & -22.15 & 8.83 & 27.90 \\
\hline $701-2-3 d$ & 0.88 & -20.37 & 11.60 & 27.60 \\
\hline $701-2-3$ & 0.98 & -22.26 & 18.14 & 39.22 \\
\hline $701-2-4 d$ & 1.09 & -22.29 & 11.86 & 32.88 \\
\hline $701-2-5 d$ & 1.23 & -23.37 & 13.24 & 36.67 \\
\hline $701-2-4$ & 1.33 & -22.21 & 12.67 & 33.62 \\
\hline $701-3-1 d$ & 1.41 & -23.67 & 11.07 & 34.93 \\
\hline $701-3-1$ & 1.48 & -22.29 & 9.63 & 30.13 \\
\hline $701-3-2 d$ & 1.58 & -22.78 & 12.73 & 35.27 \\
\hline $701-3-2$ & 1.68 & -20.12 & 6.02 & 19.23 \\
\hline $701-3-3 d$ & 1.78 & -23.93 & 10.73 & 36.96 \\
\hline $701-3-3$ & 1.88 & -22.45 & 8.92 & 28.42 \\
\hline $701-3-4 d$ & 1.98 & -23.13 & 10.44 & 32.03 \\
\hline $701-3-5 d$ & 2.07 & -22.50 & 11.09 & 31.98 \\
\hline 701-3-4 & 2.18 & -22.62 & 6.10 & 23.39 \\
\hline $701-3-6 d$ & 2.26 & -22.49 & 12.52 & 34.67 \\
\hline $701-4-1 d$ & 2.32 & -22.58 & 6.68 & 25.32 \\
\hline $701-4-2 d$ & 2.37 & -22.39 & 7.31 & 24.65 \\
\hline $701-4-3 d$ & 2.42 & -21.97 & 8.15 & 25.45 \\
\hline $701-4-4 d$ & 2.47 & -21.52 & 8.37 & 24.33 \\
\hline $701-4-5 d$ & 2.52 & -21.67 & 8.80 & 26.84 \\
\hline $701-4-6 d$ & 2.57 & -22.04 & 8.99 & 27.90 \\
\hline $701-4-7 d$ & 2.62 & -22.36 & 9.62 & 30.13 \\
\hline $701-4-8 d$ & 2.67 & -22.30 & 9.29 & 28.42 \\
\hline $701-4-9 d$ & 2.72 & -22.26 & 10.43 & 30.13 \\
\hline 701-4-10d & 2.77 & -21.73 & 9.84 & 28.68 \\
\hline $701-4-11 d$ & 2.82 & -21.80 & 11.17 & 30.79 \\
\hline $701-4-12 d$ & 2.87 & -21.65 & 13.39 & 32.25 \\
\hline $701-4-13 d$ & 2.92 & -21.74 & 13.82 & 33.26 \\
\hline $701-4-14 d$ & 2.97 & -21.87 & 15.81 & 36.24 \\
\hline
\end{tabular}




\section{Continued}

\begin{tabular}{|c|c|c|c|c|}
\hline $701-4-15 d$ & 3.02 & -21.75 & 14.76 & 34.23 \\
\hline $701-4-16 d$ & 3.07 & -22.18 & 15.34 & 35.78 \\
\hline $701-4-17 d$ & 3.12 & -21.95 & 13.98 & 34.20 \\
\hline $701-4-18 d$ & 3.17 & -21.42 & 16.63 & 35.52 \\
\hline $701-4-19 d$ & 3.22 & -21.94 & 18.65 & 39.05 \\
\hline $701-4-20 d$ & 3.27 & -22.16 & 18.78 & 39.57 \\
\hline $701-5-1 d$ & 3.32 & -22.10 & 46.96 & 61.06 \\
\hline $701-5-2 d$ & 3.37 & -23.57 & 33.51 & 53.40 \\
\hline $701-5-3 d$ & 3.42 & -23.44 & 45.92 & 61.86 \\
\hline $701-5-4 d$ & 3.47 & -23.77 & 12.30 & 37.20 \\
\hline $701-5-5 d$ & 3.52 & -24.35 & 27.45 & 49.66 \\
\hline $701-5-6 d$ & 3.57 & -24.07 & 38.10 & 56.77 \\
\hline $701-5-7 d$ & 3.61 & -23.71 & 50.15 & 64.94 \\
\hline $701-5-8 d$ & 3.63 & -24.62 & 42.72 & 60.75 \\
\hline $701-5-9 d$ & 3.64 & -24.48 & 48.85 & 64.91 \\
\hline $701-5-10 d$ & 3.67 & -24.48 & 44.10 & 61.44 \\
\hline $701-5-11 d$ & 3.72 & -24.41 & 60.25 & 72.62 \\
\hline $701-5-12 d$ & 3.75 & -24.44 & 57.28 & 70.51 \\
\hline $701-5-13 d$ & 3.76 & -25.50 & 56.66 & 72.66 \\
\hline $701-5-14 d$ & 3.78 & -24.08 & 42.55 & 60.25 \\
\hline $701-5-15 d$ & 3.82 & -24.41 & 25.82 & 49.35 \\
\hline $701-5-16 d$ & 3.87 & -24.67 & 27.06 & 50.34 \\
\hline $701-5-17 d$ & 3.92 & -25.03 & 27.15 & 50.67 \\
\hline $701-5-18 d$ & 3.97 & -24.75 & 74.02 & 82.49 \\
\hline $701-5-19 d$ & 4.02 & -24.26 & 20.51 & 45.70 \\
\hline $701-5-20 d$ & 4.07 & -24.52 & 42.42 & 60.06 \\
\hline $701-5-21 d$ & 4.12 & -24.37 & 20.83 & 45.70 \\
\hline $701-5-22 d$ & 4.17 & -24.37 & 24.40 & 47.68 \\
\hline $701-5-23 d$ & 4.22 & -24.45 & 27.44 & 50.01 \\
\hline $701-5-24 d$ & 4.27 & -24.85 & 42.77 & 60.99 \\
\hline 701-6-1 & 4.43 & -25.60 & 22.60 & 48.20 \\
\hline 701-6-1d & 4.59 & -25.34 & 75.64 & 85.09 \\
\hline $701-6-2 d$ & 4.69 & -25.45 & 49.09 & 67.08 \\
\hline $701-6-2$ & 4.78 & -25.55 & 13.53 & 42.04 \\
\hline $701-6-3 d$ & 4.89 & -24.83 & 14.47 & 42.13 \\
\hline $701-6-4 d$ & 5.00 & -23.25 & 42.36 & 58.75 \\
\hline $701-6-5 d$ & 5.09 & -24.54 & 38.48 & 57.33 \\
\hline
\end{tabular}




\section{Continued}

\begin{tabular}{|c|c|c|c|c|}
\hline $701-6-3$ & 5.18 & -25.39 & 21.77 & 47.49 \\
\hline $701-7-1 d$ & 5.32 & -24.78 & 58.46 & 71.40 \\
\hline $701-7-1$ & 5.42 & -24.75 & 21.07 & 46.52 \\
\hline $701-7-2 d$ & 5.55 & -24.01 & 51.44 & 65.87 \\
\hline $701-7-3 d$ & 5.75 & -23.43 & 64.62 & 75.22 \\
\hline $701-7-2$ & 5.78 & -25.43 & 13.19 & 41.30 \\
\hline $701-7-4 d$ & 5.88 & -22.53 & 64.30 & 73.93 \\
\hline $701-7-3$ & 5.98 & -26.39 & 19.34 & 45.99 \\
\hline $701-7-4$ & 6.22 & -24.23 & 14.49 & 40.88 \\
\hline $701-8-1$ & 6.35 & -24.16 & 11.92 & 38.18 \\
\hline $701-8-2$ & 6.60 & -23.60 & 7.26 & 28.52 \\
\hline $701-8-3$ & 6.65 & -23.58 & 11.12 & 34.93 \\
\hline $702-1-1$ & 0.10 & -22.47 & 8.99 & 28.42 \\
\hline $702-1-1 d$ & 0.23 & -22.54 & 13.59 & 35.83 \\
\hline $702-1-2$ & 0.35 & -22.62 & 9.38 & 29.00 \\
\hline $702-1-2 d$ & 0.48 & -22.85 & 12.74 & 35.27 \\
\hline $702-1-3$ & 0.60 & -23.03 & 9.12 & 30.40 \\
\hline $702-1-3 d$ & 0.76 & -22.18 & 12.11 & 32.43 \\
\hline $702-1-4$ & 0.90 & -22.98 & 12.12 & 34.67 \\
\hline $702-2-1 d$ & 1.01 & -22.64 & 14.30 & 35.83 \\
\hline $702-2-2 d$ & 1.06 & -23.14 & 16.06 & 39.12 \\
\hline $702-2-3 d$ & 1.11 & -23.31 & 12.07 & 35.43 \\
\hline $702-2-4 d$ & 1.16 & -22.64 & 12.99 & 34.67 \\
\hline $702-2-5 d$ & 1.21 & -22.42 & 15.03 & 36.33 \\
\hline $702-2-6 d$ & 1.26 & -22.95 & 14.15 & 36.43 \\
\hline $702-2-7 d$ & 1.31 & -22.82 & 13.83 & 36.43 \\
\hline $702-2-8 d$ & 1.36 & -22.34 & 11.91 & 32.88 \\
\hline $702-2-9 d$ & 1.41 & -22.56 & 14.20 & 35.83 \\
\hline $702-2-10 d$ & 1.46 & -22.62 & 15.61 & 37.91 \\
\hline $702-2-11 d$ & 1.51 & -22.85 & 14.59 & 37.51 \\
\hline $702-2-12 d$ & 1.56 & -22.69 & 14.25 & 35.83 \\
\hline $702-2-13 d$ & 1.61 & -22.84 & 14.94 & 37.51 \\
\hline $702-2-14 d$ & 1.66 & -22.94 & 15.76 & 38.50 \\
\hline $702-2-15 d$ & 1.71 & -23.38 & 15.40 & 38.81 \\
\hline $702-2-16 d$ & 1.76 & -23.66 & 15.87 & 40.41 \\
\hline $702-2-17 d$ & 1.81 & -24.06 & 14.10 & 40.11 \\
\hline $702-2-18 d$ & 1.86 & -23.69 & 15.17 & 40.23 \\
\hline
\end{tabular}


Continued

\begin{tabular}{|c|c|c|c|c|}
\hline $702-2-19 d$ & 1.91 & -23.43 & 17.58 & 41.47 \\
\hline $702-2-20 d$ & 1.96 & -23.39 & 20.76 & 43.81 \\
\hline $702-3-1 d$ & 2.01 & -23.40 & 14.28 & 37.79 \\
\hline $702-3-2 d$ & 2.06 & -23.31 & 19.61 & 43.05 \\
\hline $702-3-3 d$ & 2.11 & -23.07 & 14.76 & 38.14 \\
\hline $702-3-4 d$ & 2.16 & -23.29 & 22.83 & 45.28 \\
\hline $702-3-5 d$ & 2.21 & -23.45 & 20.51 & 44.30 \\
\hline $702-3-6 d$ & 2.26 & -23.40 & 25.99 & 47.43 \\
\hline $702-3-7 d$ & 2.31 & -23.56 & 18.68 & 42.82 \\
\hline $702-3-8 d$ & 2.36 & -23.48 & 19.34 & 42.82 \\
\hline $702-3-9 d$ & 2.41 & -23.50 & 24.67 & 47.14 \\
\hline $702-3-10 d$ & 2.46 & -23.59 & 24.25 & 46.44 \\
\hline $702-3-11 d$ & 2.51 & -23.27 & 20.18 & 43.05 \\
\hline $702-3-12 d$ & 2.56 & -23.22 & 51.53 & 65.92 \\
\hline $702-3-13 d$ & 2.61 & -23.52 & 21.91 & 45.02 \\
\hline $702-3-14 d$ & 2.66 & -23.88 & 28.69 & 50.29 \\
\hline $702-3-15 d$ & 2.71 & -24.73 & 30.50 & 52.94 \\
\hline $702-3-16 d$ & 2.76 & -24.83 & 74.62 & 83.16 \\
\hline $702-3-17 d$ & 2.81 & -25.26 & 42.39 & 61.94 \\
\hline $702-3-18 d$ & 2.86 & -25.51 & 36.11 & 57.70 \\
\hline $702-3-19 d$ & 2.91 & -25.36 & 73.36 & 83.29 \\
\hline $702-3-20 d$ & 2.96 & -25.01 & 74.92 & 84.37 \\
\hline $702-4-1$ & 3.08 & -26.30 & 39.07 & 60.34 \\
\hline $702-4-1 d$ & 3.22 & -24.26 & 91.11 & 92.97 \\
\hline $702-4-2$ & 3.33 & -25.66 & 56.86 & 72.76 \\
\hline $702-4-2 d$ & 3.48 & -25.62 & 84.66 & 90.62 \\
\hline $702-4-3$ & 3.58 & -25.58 & 30.87 & 54.02 \\
\hline $702-4-3 d$ & 3.73 & -24.21 & 37.24 & 56.37 \\
\hline $702-4-4$ & 3.88 & -25.90 & 30.38 & 53.65 \\
\hline $702-5-1 d$ & 4.01 & -25.91 & 40.61 & 61.63 \\
\hline $702-5-1$ & 4.11 & -25.92 & 23.14 & 48.59 \\
\hline $702-5-2 d$ & 4.23 & -25.14 & 20.95 & 46.58 \\
\hline $702-5-2$ & 4.36 & -25.99 & 15.55 & 43.56 \\
\hline $702-5-3 d$ & 4.41 & -25.84 & 16.95 & 44.30 \\
\hline $702-5-3$ & 4.51 & -25.76 & 12.30 & 40.27 \\
\hline $702-5-4 d$ & 4.56 & -23.54 & 12.30 & 36.28 \\
\hline $702-5-4$ & 4.61 & -22.92 & 39.01 & 56.03 \\
\hline
\end{tabular}




\section{Continued}

\begin{tabular}{|c|c|c|c|c|}
\hline $702-5-5 d$ & 4.71 & -23.82 & 14.78 & 40.23 \\
\hline $702-5-6 d$ & 4.82 & -24.64 & 48.02 & 64.21 \\
\hline $702-5-5$ & 4.91 & -25.75 & 26.43 & 50.56 \\
\hline $505-1-1$ & 0.17 & -22.05 & 13.65 & 34.73 \\
\hline $505-1-2$ & 0.32 & -22.18 & 13.46 & 33.62 \\
\hline $505-1-3$ & 0.47 & -22.03 & 12.92 & 33.62 \\
\hline 505-1-4 & 0.62 & -21.44 & 11.47 & 29.21 \\
\hline $505-2-1$ & 0.80 & -22.04 & 13.10 & 33.62 \\
\hline $505-2-2$ & 0.95 & -22.19 & 13.02 & 33.62 \\
\hline $505-2-3$ & 1.11 & -22.29 & 15.69 & 37.34 \\
\hline $505-2-4$ & 1.26 & -22.45 & 18.82 & 40.10 \\
\hline $505-2-5$ & 1.41 & -21.30 & 23.12 & 40.90 \\
\hline $505-2-6$ & 1.56 & -22.11 & 12.82 & 33.62 \\
\hline $505-2-7$ & 1.71 & -22.42 & 18.88 & 40.10 \\
\hline 505-3-1 & 1.87 & -22.64 & 23.68 & 44.65 \\
\hline $505-3-2$ & 2.02 & -22.96 & 16.28 & 38.50 \\
\hline $505-3-3$ & 2.17 & -22.64 & 19.47 & 40.64 \\
\hline $505-3-4$ & 2.27 & -22.85 & 11.52 & 33.99 \\
\hline $505-3-5$ & 2.37 & -22.71 & 13.88 & 35.83 \\
\hline $505-3-6$ & 2.47 & -24.79 & 16.38 & 43.37 \\
\hline $505-3-7$ & 2.57 & -21.39 & 16.91 & 35.52 \\
\hline $505-3-8$ & 2.67 & -22.29 & 12.83 & 34.12 \\
\hline 505-4-1 & 2.85 & -23.34 & 12.62 & 36.67 \\
\hline $505-4-2$ & 2.92 & -23.39 & 15.62 & 39.76 \\
\hline $505-4-3$ & 3.00 & -23.24 & 16.15 & 39.76 \\
\hline $505-4-4$ & 3.10 & -23.04 & 20.24 & 42.53 \\
\hline $505-4-5$ & 3.20 & -23.35 & 24.46 & 46.00 \\
\hline 505-4-6 & 3.30 & -23.48 & 15.95 & 40.41 \\
\hline $505-4-7$ & 3.40 & -22.38 & 24.48 & 44.20 \\
\hline $505-4-8$ & 3.50 & -21.00 & 24.59 & 41.68 \\
\hline 505-4-9 & 3.60 & -23.54 & 30.27 & 50.62 \\
\hline $505-4-10$ & 3.70 & -23.94 & 76.49 & 83.37 \\
\hline $505-5-1$ & 3.84 & -23.98 & 60.52 & 72.95 \\
\hline $505-5-2$ & 3.94 & -23.95 & 73.01 & 81.33 \\
\hline $505-5-3$ & 4.02 & -24.52 & 22.92 & 47.41 \\
\hline $505-5-4$ & 4.10 & -25.09 & 15.00 & 42.48 \\
\hline $505-5-5$ & 4.20 & -25.27 & 61.87 & 75.97 \\
\hline
\end{tabular}




\section{Continued}

\begin{tabular}{|c|c|c|c|c|}
\hline $505-5-6$ & 4.30 & -25.16 & 56.50 & 72.56 \\
\hline $505-5-7$ & 4.40 & -25.20 & 24.17 & 48.70 \\
\hline $505-5-8$ & 4.50 & -25.06 & 33.33 & 55.14 \\
\hline $505-5-9$ & 4.60 & -24.80 & 20.73 & 46.51 \\
\hline $505-5-10$ & 4.70 & -24.96 & 35.54 & 57.38 \\
\hline $505-6-1$ & 4.84 & -24.67 & 31.99 & 53.60 \\
\hline $505-6-2$ & 4.92 & -23.04 & 82.05 & 86.65 \\
\hline $505-6-3$ & 5.02 & -24.01 & 87.14 & 90.47 \\
\hline $505-6-4$ & 5.12 & -24.85 & 49.08 & 65.12 \\
\hline $505-6-5$ & 5.22 & -25.42 & 24.81 & 49.63 \\
\hline $505-6-6$ & 5.32 & -23.73 & 35.55 & 55.10 \\
\hline $505-6-7$ & 5.42 & -23.72 & 25.59 & 48.24 \\
\hline $505-6-8$ & 5.52 & -23.65 & 21.34 & 44.30 \\
\hline $505-6-9$ & 5.62 & -24.58 & 29.40 & 51.32 \\
\hline $505-6-10$ & 5.72 & -25.29 & 27.94 & 51.61 \\
\hline $505-7-1$ & 5.84 & -25.08 & 28.95 & 52.15 \\
\hline $505-7-2$ & 5.92 & -25.04 & 68.32 & 79.88 \\
\hline $505-7-3$ & 6.02 & -24.95 & 57.06 & 72.47 \\
\hline $505-7-4$ & 6.12 & -24.82 & 37.69 & 57.59 \\
\hline $505-7-5$ & 6.22 & -24.96 & 87.73 & 92.05 \\
\hline $505-7-6$ & 6.32 & -24.97 & 34.82 & 56.63 \\
\hline $505-7-7$ & 6.42 & -25.09 & 64.71 & 77.89 \\
\hline $505-7-8$ & 6.52 & -25.17 & 61.07 & 75.30 \\
\hline $505-7-9$ & 6.62 & -25.04 & 62.81 & 76.55 \\
\hline $505-7-10$ & 6.72 & -25.01 & 88.14 & 92.05 \\
\hline $505-8-1$ & 6.84 & -24.90 & 23.72 & 48.47 \\
\hline $505-8-2$ & 6.92 & -24.42 & 40.24 & 58.69 \\
\hline $505-8-3$ & 7.02 & -24.81 & 44.78 & 62.36 \\
\hline $505-8-4$ & 7.12 & 23.40 & 69.65 & 78.74 \\
\hline $505-8-5$ & 7.22 & -25.68 & 70.69 & 82.09 \\
\hline $505-8-6$ & 7.32 & -25.01 & 41.96 & 61.80 \\
\hline $505-8-7$ & 7.42 & -24.13 & 49.81 & 65.16 \\
\hline $505-8-8$ & 7.52 & -24.54 & 77.83 & 85.02 \\
\hline $505-8-9$ & 7.62 & -24.55 & 41.07 & 59.37 \\
\hline $505-8-10$ & 7.72 & -24.53 & 25.58 & 49.35 \\
\hline $505-9-1$ & 7.89 & -24.36 & 47.09 & 63.28 \\
\hline $505-9-2$ & 8.12 & -24.57 & 46.26 & 62.82 \\
\hline
\end{tabular}


A. F. M. FREIRE, M. C. MONTEIRO

\begin{tabular}{|c|c|c|c|c|}
\hline $505-9-3$ & 8.34 & -24.72 & 42.37 & 60.31 \\
\hline $505-9-4$ & 8.52 & -24.52 & 49.06 & 64.91 \\
\hline $505-9-5$ & 8.67 & -24.63 & 50.55 & 66.30 \\
\hline
\end{tabular}

